\title{
KEMAMPUAN MANAJEMEN KELAS GURU: PENELITIAN TINDAKAN DI SEKOLAH DASAR DENGAN SES RENDAH
}

\author{
Helsa, Agustina Hendriati \\ Fakultas Psikologi Universitas Katolik Indonesia Atma Jaya Jakarta \\ Jalan Jendral Sudirman 51 Setiabudi Jakarta Selatan \\ helsa.surya@gmail.com
}

\begin{abstract}
This is an action research that aims to identify and improve classroom management skill of six homeroom teachers in a low socio-economic elementary school. Classroom management skill is defined as teacher's ability to create and maintain a learning environment that conducive to learning. The classroom management skill is measured using an observation-based rating scales and semi-structured interviews. The findings showed that classroom management skills were lacking among the majority of participants because they did not have sufficient knowledge about classroom management and did not understand their class' needs. After two periods of intervention, the participants' classroom management skill is improved. It was revealed that individual coaching is more effective than training method in improving classroom management skill. Furthermore, educational background and previous professional experience influenced participants' classroom management skill. However, participants with the relevant educational background do not automatically master classroom management skill, unless supported with professional experience.
\end{abstract}

Keywords: classroom management; low socio-economic school; action research

\begin{abstract}
Abstrak
Penelitian ini merupakan penelitian tindakan yang bertujuan untuk mengetahui dan meningkatkan kemampuan manajemen kelas para wali kelas di SD X yang berlatarbelakang sosial ekonomi rendah. Kemampuan manajemen kelas adalah kemampuan guru untuk menciptakan situasi belajar kondusif. Gambaran kemampuan manajemen kelas diukur melalui observasi dengan skala rating dan diperdalam dengan wawancara semi terstruktur, sehingga diperoleh gambaran kemampuan manajemen kelas keenam partisipan. Temuan penelitian menunjukkan bahwa mayoritas partisipan kurang memiliki kemampuan manajemen kelas yang baik karena tidak memahami manajemen kelas dan tidak mengenali kebutuhan kelasnya. Setelah menjalani dua siklus intervensi, kemampuan manajemen kelas para partisipan meningkat. Partisipan ditemukan lebih memahami manajemen kelas dan mampu menerapkannya di kelas masing-masing. Metode individual coaching ditemukan lebih efektif dalam meningkatkan kemampuan manajemen kelas dibandingkan dengan pelatihan. Temuan penelitian juga menunjukkan bahwa partisipan yang memiliki latar belakang pendidikan guru dan pengalaman kerja yang memadai memiliki kemampuan manajemen kelas yang baik. Di samping itu, partisipan dengan latar belakang pendidikan guru tidak otomatis menguasai kemampuan manajemen kelas, kecuali bila didukung dengan pengalaman kerja yang memadai.
\end{abstract}

Kata kunci: manajemen kelas; sekolah SES rendah; penelitian tindakan

\section{PENDAHULUAN}

Di antara seluruh jenjang pendidikan di lembaga pendidikan formal, jenjang pendidikan Sekolah Dasar (SD) merupakan tahap pendidikan pertama yang penting dilalui oleh peserta didik. Jenjang pendidikan SD merupakan tahap pertama yang ditempuh peserta peserta didik untuk mendapat pembekalan pengetahuan, sikap, dan keterampilan dasar yang berguna dalam mengikuti pendidikan di jenjang selanjutnya (Rachman, 2015). Oleh sebab itu, penting bagi peserta didik untuk belajar secara optimal di jenjang ini. 
Untuk mendukung optimalisasi pembelajaran peserta didik di SD, maka guru dipercaya memiliki peranan penting di dalamnya. Sa'diyah dan Sukayati (2011) menyatakan bahwa di jenjang SD, keberhasilan belajar siswa sebagian besar bergantung pada usaha guru dalam memfasilitasi siswa saat proses pembelajaran berlangsung. Guru secara langsung mempengaruhi bagaimana siswa belajar, apa yang dipelajari, seberapa banyak siswa belajar, dan pola interaksi di dalam kelas maupun interaksi dengan lingkungan yang lebih luas.

Pentingnya peran guru dalam pembelajaran siswa SD membuat guru perlu memiliki berbagai kemampuan yang menunjangnya dalam menciptakan proses pembelajaran yang efektif di kelas. Goh dan Khine (2002) dalam penelitiannya di sekolahsekolah dasar di Singapura menemukan bahwa situasi kelas yang kondusif merupakan faktor penting dalam proses pembelajaran. Situasi kelas yang kondusif meliputi seluruh elemen yang berada di dalam kelas, seperti interaksi antara guru dan siswa serta iklim kelas. Situasi yang kondusif berarti ada interaksi yang positif dan asertif antara guru dan siswanya dalam mengemukakan kebutuhan dan keinginannya di kelas, adanya perhatian yang adil bagi guru kepada seluruh siswa, serta adanya lingkungan fisik yang mendukung siswa untuk fokus dalam pembelajaran. Situasi kelas yang kondusif dapat meningkatkan keinginan siswa untuk belajar. Hal ini menandakan adanya hubungan yang signifikan antara situasi belajar yang kondusif dengan hasil pembelajaran.

Melihat pentingnya situasi belajar yang kondusif dalam proses pembelajaran dan pencapaian akademik siswa, maka guru perlu memiliki kemampuan untuk menciptakan situasi kondusif di kelas. Dalam hal ini, kemampuan guru dalam mengelola atau mengatur kelasnya menjadi penting. Henley (dalam Emmer \& Stough,
2001) menyatakan bahwa pengelolaan atau manajemen kelas adalah kemampuan mengajar yang penting bagi guru, karena dapat mengurangi gangguan di dalam kelas dan menciptakan lingkungan belajar untuk mendukung perkembangan intelektual dan emosional siswa.

Pentingnya kemampuan manajemen kelas juga didukung oleh hasil penelitian Ratcliff dkk. (2011). Temuan penelitian menunjukkan ketika guru dapat menciptakan suasana kelas yang kondusif untuk belajar, maka waktu untuk menangani permasalahan dalam kelas akan berkurang, sehingga waktu yang digunakan untuk proses belajar mengajar menjadi semakin meningkat.

Pada dasarnya, kemampuan manajemen kelas dibutuhkan oleh guru yang mengajar siswa di semua jenjang usia. Hal ini dikarenakan siswa perlu belajar untuk memahami dan mengikuti keteraturan atau struktur di sekolah. Akan tetapi, Sa'diyah dan Sukayati (2011) menyatakan bahwa masih banyak guru yang kurang maksimal dalam mengelola kelas yang diampunya, terutama di sekolah dasar-sekolah dasar di Indonesia.

Kenyataannya, mengajarkan struktur kepada siswa dengan latar belakang ekonomi rendah menjadi tantangan tersendiri, karena mereka memiliki karakteristik unik yang berdampak pada timbulnya masalah perilaku para siswa ini di sekolah. McGrath dan Elgar (2015) menyebutkan bahwa anak dengan SES umumnya kurang memiliki hubungan yang mendukung dan stabil dengan orangtuanya. Hal ini dikarenakan salah satu atau kedua orangtua harus bekerja sepanjang hari sehingga anak tidak mendapat pengalaman yang cukup positif untuk mempelajari respon emosi dari situasi sehari-hari (Jensen, 2013).

Hal ini juga disampaikan oleh Willingham (2012) yang menuturkan bahwa orang tua 
dari SES rendah cenderung menerapkan pengasuhan yang kasar dan tidak konsisten, sehingga berdampak pada permasalahan perilaku dan emosi pada anaknya. Permasalahan ini berupa mengucapkan kata-kata kasar atau mengejek orang lain, berkelahi secara fisik, melakukan tindak bullying, dan sikap tidak patuh.

Smith (2012) menyebutkan bahwa kurangnya pemahaman guru akan budaya sekolah menjadi salah satu faktor penting sulitnya mengendalikan perilaku siswa dari kalangan SES rendah. Di dalam keluarga, anak-anak ini juga kurang mendapatkan pelajaran implisit mengenai bagaimana meresponi permintaan dan bersikap sesuai dengan situasi yang dialaminya saat itu, sehingga menimbulkan masalah perilaku di kelas. Anak dari kalangan SES rendah tidak terbiasa dengan kegiatan yang terstruktur seperti anak-anak dari kalangan SES yang lebih tinggi. Perbedaan budaya di sekolah dan rumah menyebabkan anak mengalami masalah perilaku saat masuk sekolah. Masalah perilaku ini meliputi perilaku mengganggu teman di kelas, bersikap tidak sopan terhadap teman maupun guru, keengganan mengikuti pembelajaran di kelas, dan tidak mau mematuhi perkataan guru.

Beragam masalah perilaku ini juga terjadi di SD X yang berlokasi di wilayah Jakarta Utara, berdekatan dengan Pelabuhan Tanjung Priok. SD X merupakan sekolah dasar berlatar sosial ekonomi rendah. Para orang tua siswa di sekolah ini umumnya bekerja sebagai buruh pabrik, anak buah kapal (ABK), pedagang kecil, pengumpul sampah, tukang mencuci pakaian, dan asisten rumah tangga. Oleh karena itu, mayoritas siswa mendapatkan Kartu Jakarta Pintar (KJP) dari Pemerintah Provinsi DKI Jakarta agar dapat membantu membiayai pendidikan mereka. SD X memiliki enam wali kelas dan 140 siswa. Pihak sekolah menyatakan bahwa suasana kelas seringkali tidak teratur, sehingga kurang kondusif untuk belajar. Ketidakteraturan ini berupa perilaku siswa yang kerap mengganggu siswa lain, sikap melawan guru, dan keengganan mengikuti aktivitas pembelajaran di kelas. Akibatnya, para wali kelas kerap menegur siswa dengan cara berteriak atau memberi hukuman. Berbagai hukuman telah diterapkan, namun dinilai tidak memberikan efek jera bagi siswa.

Irvin dkk. (dalam Jensen, 2013) mempercayai bahwa membangun hubungan yang kuat dengan melibatkan siswanya secara aktif dalam proses pembelajaran adalah salah satu strategi manajemen kelas yang efektif bagi siswa dengan SES rendah. Di samping itu, Smith (2012) dalam penelitiannya terhadap siswa dari kalangan SES rendah mendapati bahwa rutinitas dan aturan sangat penting bagi anak-anak ini. Hal ini dikarenakan mereka tidak terbiasa dengan adanya struktur, padahal struktur sangat diperlukan di sekolah. Smith (2012) menemukan bahwa rutinitas dan aturan akan lebih dapat dipatuhi siswa bila diajarkan secara implisit. Artinya, guru melibatkan siswa dalam interaksi yang dapat dilakukan dengan menggunakan contoh-contoh atau menggunakan pertanyaan dalam mengajarkan rutinitas dan aturan. Selanjutnya, Smith (2012) juga menekankan pentingnya pemberian konsekuensi perilaku. Bimbingan menggunakan bahasa verbal lebih efektif bagi siswa dengan SES rendah. Bila siswa tidak meresponinya, maka guru dapat mengambil tindakan.

Keempat hal penting dalam manajemen kelas seperti yang telah disebutkan di atas sangat sesuai dengan teori manajemen kelas dari Simonsen, Fairbanks, Briesch, Myers, dan Sugai (2008). Menurut Simonsen dkk. (2008), manajemen kelas memiliki lima aspek, yaitu memaksimalkan struktur, membuat dan menerapkan harapan, melibatkan siswa secara aktif, menggunakan rangkaian 
strategi untuk memperkuat dan melemahkan perilaku siswa. Kelima aspek ini penting diterapkan agar tercipta suasana kondusif dalam belajar. Dengan demikian, kelima aspek ini relevan diterapkan di sekolah dengan SES rendah, termasuk SD $\mathrm{X}$.

Situasi kelas di SD X menunjukkan bahwa para guru masih kesulitan untuk menciptakan situasi yang kondusif untuk belajar. Beberapa guru menyatakan sudah membuat peraturan kelas, namun tidak ditaati para siswa. Berbagai hukuman juga sudah diterapkan untuk menimbulkan efek jera, namun para siswa tetap mengulangi perilaku tidak tertib di kelas. Padahal, penerapan peraturan dan hukuman yang efektif merupakan dua dari lima aspek penting dalam manajemen kelas yang perlu diterapkan guru. Kendala-kendala ini memunculkan dugaan bahwa para guru sebenarnya kurang memiliki kemampuan manajemen kelas yang baik, sehingga kesulitan untuk menciptakan pembelajaran yang optimal di kelas.

Penelitian ini merupakan penelitian tindakan yang bertujuan memperlengkapi atau meningkatkan kemampuan partisipan agar dapat memperbaiki performanya (Sagor, 2000). Oleh sebab itu, penelitian ini bertujuan untuk mengetahui dan meningkatkan kemampuan manajemen kelas para guru di SD X. Dengan demikian, pemberian intervensi diharapkan dapat memperlengkapi para guru terkait kemampuan manajemen kelas, sehingga dapat memiliki situasi belajar yang lebih kondusif.

\section{METODE}

Penelitian merupakan penelitian tindakan, yaitu penelitian yang bertujuan memperlengkapi atau meningkatkan kemampuan partisipan dalam menghadapi situasi yang dialaminya (Greenwood \& Levin, 2007). Penelitian ini merupakan penelitian tindakan karena peneliti ingin agar para partisipan memiliki kemampuan dalam menentukan hal-hal apa saja yang dibutuhkan kelasnya terkait dengan manajemen kelas, sehingga para partisipan dapat juga menerapkannya secara mandiri di tahun-tahun ajaran berikutnya. Dalam penelitian ini dilakukan dua siklus. Pada siklus pertama, peneliti mengambil data awal (baseline) tentang kemampuan manajemen kelas partisipan, menyusun dan melaksanakan intervensi berdasarkan data baseline, dan melakukan evaluasi intervensi. Pada siklus kedua, peneliti menyusun dan melaksanakan intervensi kedua berdasarkan data evaluasi intervensi pertama, lalu melakukan evaluasi intervensi kedua. Dengan kedua siklus ini, diharapkan para partisipan dapat semakin menyempurnakan kemampuan manajemen kelasnya.

Pendekatan yang digunakan adalah explanatory sequential mixed methods design. Menurut Tashakkori dan Teddlie (2010), desain ini merupakan desain mixed method yang paling tajam. Tujuan utamanya adalah menggunakan data kualitatif untuk menjelaskan data kuantitatif secara lebih mendalam. Pada pendekatan ini, pengambilan data didahului dengan melakukan observasi terstruktur dengan skala rating, yaitu dengan mengobservasi aktivitas partisipan di kelas terkait manajemen kelas, lalu memperdalam hasil observasi tersebut dengan wawancara semi terstruktur. Adapun rincian kegiatan di masing-masing tahap adalah sebagai berikut:

1. Siklus pertama

Siklus pertama terdiri dari:

a. Pengambilan dan analisis data baseline (plan)

Pada tahap ini, peneliti melakukan observasi dengan skala rating (akan dijelaskan lebih detail di halaman berikutnya) dan diperdalam dengan wawancara semi terstruktur untuk mengetahui kemampuan manajemen kelas 
keenam guru. Peneliti juga menggali mengenai latar belakang pendidikan dan pengalaman kerja para guru. Kemudian, analisis dilakukan untuk mengetahui gambaran awal kemampuan manajemen kelas para guru dan memetakan aspek manajemen kelas yang kurang dimiliki oleh mayoritas guru.

b. Perencanaan intervensi pertama (plan)

Berdasarkan pemetaan aspek manajemen kelas yang kurang dimiliki oleh mayoritas guru, peneliti merancang intervensi berupa pelatihan. Hal ini dikarenakan pelatihan lebih menekankan praktik daripada teori dan bertujuan meningkatkan kemampuan dalam satu atau berbagai jenis keterampilan tertentu (Santoso, 2010), sehingga cocok dengan tujuan peneliti yang ingin meningkatkan kemampuan manajemen kelas para guru. Adapun materi pelatihan mencakup empat aspek manajemen kelas, yaitu adalah penerapan rutinitas, mengajarkan peraturan kelas, menggunakan strategi penguatan perilaku lain, dan menggunakan strategi pelemahan perilaku lain. Pelatihan dirancang dan diberikan oleh peneliti sendiri. Pelatihan dilaksanakan di hari yang ditentukan bersama-sama dengan para partisipan seusai aktivitas belajar mengajar berakhir.

c. Pelaksanaan intervensi pertama (act)

Pelatihan dilakukan kepada keenam guru seusai jam sekolah. Dua hari sebelumnya, peneliti memberikan buku materi agar para guru dapat membacanya terlebih dahulu sebelum pelatihan berlangsung.

d. Pengambilan data evaluasi pasca intervensi pertama (observe)

Peneliti melakukan observasi dengan skala rating dan refleksi untuk mengetahui kemampuan manajemen kelas para partisipan setelah pelatihan. Pengambilan data ini dilakukan dua minggu setelah pelatihan berlangsung.

e. Evaluasi dan refleksi hasil intervensi pertama (reflect)

Peneliti menganalisis hasil pengambilan data evaluasi pasca pelatihan dan melakukan refleksi pribadi untuk dijadikan dasar perancangan intervensi kedua.

2. Siklus kedua

Siklus kedua terdiri dari:

a. Perencanaan intervensi kedua (plan)

Berdasarkan hasil evaluasi intervensi pertama, maka peneliti merancang coaching individual untuk keempat partisipan yang masih dapat dikembangkan kemampuannya. Coaching adalah bentuk pengembangan profesional yang bertujuan mengembangkan potensi seseorang secara maksimal, menemukan kekuatan dan kemampuannya, dan membangun kinerja yang efektif (Aguilar, 2013). Becker, Darney, Domitrovich, Keperling, dan Ialongo (2013) berpendapat bahwa coaching secara personal dapat dilakukan sebagai intervensi lanjutan dari sebuah pelatihan. Hal ini dikarenakan guru yang lebih banyak menerima performance feedback melalui coaching cenderung memiliki tingkat implementasi lebih tinggi bila dibandingkan dengan guru yang lebih sedikit menerima performance feedback 
(Reinke, Stormont, Herman, \& Newcomer, 2014).

Dalam proses penelitian, peneliti juga mendapati bahwa para partisipan cenderung lebih memiliki keterbukaan berdiskusi dalam situasi personal dibandingkan kelompok, sehingga peneliti memutuskan untuk menggunakan coaching dengan harapan mereka dapat lebih terbuka berdiskusi mengenai hambatan yang dialami dan manajemen kelas yang dapat diterapkan di kelas masing-masing. Adapun materi coaching setiap partisipan berbeda-beda, bergantung dari hasil observasi di tahap evaluasi pasca intervensi siklus pertama. Aspek-aspek manajemen kelas yang didapati masih kurang berkembang setelah intervensi siklus pertama akan kembali dikembangkan melalui intervensi kedua berupa coaching.

b. Pelaksanaan intervensi kedua (act)

Coaching individual dilakukan selama 1,5 hingga 2 jam kepada masing-masing partisipan. Waktu pelaksanaan coaching masing-masing partisipan disesuaikan dengan waktu luang yang dimiliki. Dalam coaching, peneliti mengajak partisipan untuk menggali hal-hal yang cocok dan dapat diterapkan di kelasnya.

c. Pengambilan data evaluasi pasca intervensi kedua (observe)

Peneliti melakukan observasi dengan skala rating dan wawancara untuk mengetahui kemampuan manajemen kelas para partisipan setelah coaching. Pengambilan data ini dilakukan satu minggu setelah coaching berlangsung.

d. Evaluasi dan refleksi hasil intervensi kedua (reflect)

Di tahap terakhir ini, peneliti menganalisis hasil pengambilan data evaluasi pasca coaching untuk melihat apakah terjadi peningkatan kemampuan manajemen kelas para partisipan setelah diberikan intervensi.

Kedua siklus di atas berlangsung dari bulan Oktober 2016 hingga Desember 2016. Penelitian ini dilakukan di SD X, yaitu sebuah sekolah swasta yang mayoritas siswanya berlatar belakang SES rendah di daerah Jakarta Utara. Penelitian ini melibatkan enam wali kelas di SD X. Observasi dilakukan di masing-masing kelas yang diampu wali kelas, yaitu selama 2,5 hingga 3 jam setiap sesi, di mana peneliti mengobservasi dua sesi untuk setiap wali kelas di hari yang berbeda. Sementara itu, wawancara dilakukan sepulang sekolah setelah para wali kelas selesai mengajar. Masing-masing wali kelas memiliki jumlah siswa yang berbedabeda di kelasnya, yaitu sebagai berikut:

Tabel 1.

Jumlah Siswa per Kelas

\begin{tabular}{ll}
\hline Kelas & Jumlah Siswa \\
\hline I & 12 siswa \\
II & 23 siswa \\
III & 22 siswa \\
IV & 26 siswa \\
V & 20 siswa \\
VI & 21 siswa \\
\hline
\end{tabular}

Adapun panduan observasi dan wawancara disusun berdasarkan teori manajemen kelas dari Simonsen dkk. (2008). Panduan observasi dengan skala rating yang terdiri dari 10 item dengan masing-masing terdiri dari empat skala, yaitu kurang (skor 1), cukup (skor 2), baik (skor 3), dan sangat baik (skor 4). Kesepuluh item ini mengukur lima aspek kemampuan 
manajemen kelas dari Simonsen, di mana masing-masing aspek terdiri dari dua item. Kelima aspek tersebut adalah: 1) memaksimalkan struktur kelas, 2) membuat, mengajarkan, melakukan review, memonitor, dan memperkuat harapan/aturan, 3) melibatkan siswa secara aktif, 4) menggunakan rangkaian strategi untuk merespon perilaku siswa yang diharapkan muncul, dan 5) menggunakan rangkaian strategi untuk melemahkan perilaku siswa yang tidak diharapkan muncul.

Tidak dilakukan perbedaan item-item pada instrumen penelitian untuk kelas kecil (kelas I sampai III) dan kelas besar (kelas IV sampai VI). Hal ini dikarenakan fokus penelitian ini adalah penelitian tindakan mengenai manajemen kelas dan tidak dilakukan perbandingan antar kelas, sehingga adaptasi instrumen penelitian untuk kelas kecil dan besar dirasa tidak diperlukan.

Panduan observasi telah melalui proses uji coba dengan expert judgment kepada seorang dosen Fakultas Pendidikan dan Ilmu Pengetahuan UNIKA Atma Jaya Jakarta dengan program kekhususan Pendidikan Guru Sekolah Dasar (SD) yang memiliki keahlian dalam bidang keterampilan dasar mengajar, strategi pembelajaran, dan penelitian tindakan kelas. Setelah melalui proses expert judgment, peneliti juga melakukan interrater agreement, yaitu dengan menghitung persentase pemberian skor yang sama (agreement) antara dua rater. Dalam hal ini, yang menjadi rater adalah peneliti sendiri dan seorang teman peneliti dari jurusan Psikologi. Persentase inter-rater agreement adalah sebesar $80 \%$, menandakan bahwa panduan observasi dapat menjadi alat pengambilan data yang kredibel (Graham, Milanowski, \& Miller, 2012).

Analisis data observasi dilakukan dengan teknik statistika dasar. Pertama-tama, peneliti menghitung total skor kemampuan manajemen kelas masing-masing partisipan sehingga dapat menemukan rataan ideal $(M)$ sebesar 25 dan standar deviasi ideal (SD) sebesar 5, sehingga dapat diketahui pembagian kategori dari total skor. Pembagian kategori dimulai dari sangat kurang, kurang, cukup, baik, dan sangat baik. Setelah mengolah data observasi, peneliti melakukan wawancara untuk mendalami hasil observasi. Analisis data penelitian juga menggunakan teknik content analysis. Analisis data akan disusun dengan menggunakan kode informasi (coding), yang bertujuan mengorganisasi dan membuat sistem data secara lengkap dan detail, sehingga dapat lebih memahami gambaran topik yang sedang diteliti (Poerwandari, 2009). Melalui hasil observasi dan wawancara, peneliti kemudian membuat kesimpulan deskriptif mengenai kemampuan manajemen kelas masing-masing partisipan.

\section{HASIL DAN PEMBAHASAN}

Pada bagian ini, peneliti akan membahasnya ke dalam 4 bagian, yaitu (1) latar belakang pendidikan dan pengalaman kerja, (2) baseline, yaitu gambaran kemampuan awal partisipan sebelum diberikan intervensi, (3) evaluasi pasca intervensi pertama, yaitu hasil observasi dan wawancara setelah partisipan mengikuti pelatihan, dan (4) evaluasi pasca intervensi kedua, yaitu hasil observasi dan wawancara setelah partisipan mengikuti coaching individual. Peneliti juga membandingkan kemampuan para partisipan menggunakan grafik.

Tabel 2 menunjukkan bahwa para partisipan memiliki latar belakang pendidikan dan pengalaman bekerja di dunia pendidikan yang berbeda-beda. Terdapat dua partisipan yang latar belakang pendidikan guru dan berpengalaman bekerja sebagai tenaga pengajar cukup lama (kelas I dan VI), dua partisipan tidak memiliki latar belakang 
pendidikan guru dan sama sekali tidak pernah mengajar (kelas IV dan V), satu partisipan memiliki latar pendidikan guru namun minim pengalaman mengajar (kelas III), dan satu partisipan tidak memiliki latar belakang pendidikan dengan minim pengalaman mengajar (kelas II).

Tabel 2.

Latar Belakang Pendidikan dan

Pengalaman Bekerja Partisipan

\begin{tabular}{lll}
\hline $\begin{array}{l}\text { Wali } \\
\text { Kelas }\end{array}$ & $\begin{array}{l}\text { Latar Belakang } \\
\text { Pendidikan }\end{array}$ & $\begin{array}{l}\text { Pengalaman Bekerja } \\
\text { di Dunia Pendidikan }\end{array}$ \\
\hline I & PAUD & 10 tahun \\
II & Akademi & 2 tahun \\
& Bahasa Inggris & \\
III & PGSD & $<1$ tahun \\
IV & Teologia & Belum pernah \\
V & Komputer & Belum pernah \\
VI & PGSD & 7 tahun \\
\hline
\end{tabular}

Selanjutnya berdasarkan hasil observasi awal (data baseline), maka didapat skor keenam partisipan seperti tersaji dalam Tabel 3.

Tabel 3.

Perolehan Skor Observasi Baseline

\begin{tabular}{|c|c|c|c|c|c|c|c|}
\hline \multirow{2}{*}{ No } & \multirow{2}{*}{ Aspek } & \multicolumn{6}{|c|}{ Kelas } \\
\hline & & I & II & III & IV & $\mathbf{V}$ & VI \\
\hline \multirow[t]{2}{*}{1} & Rutinitas & 4 & 1 & 2 & 1 & 1 & 4 \\
\hline & Pengaturan ruang & 4 & 2 & 2 & 3 & 2 & 4 \\
\hline \multirow[t]{2}{*}{2} & $\begin{array}{l}\text { Mengajarkan } \\
\text { aturan }\end{array}$ & 3 & 3 & 1 & 1 & 1 & 3 \\
\hline & $\begin{array}{l}\text { Menerapkan } \\
\text { aturan }\end{array}$ & 4 & 4 & 3 & 3 & 3 & 4 \\
\hline \multirow[t]{2}{*}{3} & $\begin{array}{l}\text { Menggunakan } \\
\text { choral } \\
\text { responding dan } \\
\text { response cards }\end{array}$ & 2 & 2 & 2 & 2 & 2 & 4 \\
\hline & $\begin{array}{l}\text { Metode mengajar } \\
\text { yang lain }\end{array}$ & 3 & 2 & 2 & 2 & 2 & 3 \\
\hline \multirow[t]{2}{*}{4} & $\begin{array}{l}\text { Menggunakan } \\
\text { pujian untuk } \\
\text { apresiasi }\end{array}$ & 4 & 4 & 3 & 3 & 4 & 4 \\
\hline & $\begin{array}{l}\text { Menggunakan } \\
\text { strategi } \\
\text { penguatan } \\
\text { perilaku lain }\end{array}$ & 2 & 1 & 1 & 1 & 1 & 3 \\
\hline \multirow[t]{2}{*}{5} & $\begin{array}{l}\text { Menggunakan } \\
\text { teguran }\end{array}$ & 4 & 4 & 2 & 3 & 2 & 4 \\
\hline & $\begin{array}{l}\text { Menggunakan } \\
\text { strategi } \\
\text { pelemahan } \\
\text { perilaku lain }\end{array}$ & 2 & 2 & 2 & 2 & 2 & 2 \\
\hline \multicolumn{2}{|c|}{ Total Skor } & 32 & 25 & 20 & 21 & 20 & 35 \\
\hline \multicolumn{2}{|c|}{ Kategori } & 4 & 3 & 2 & 2 & 2 & 5 \\
\hline
\end{tabular}

Keterangan: Kategori: 1= sangat kurang, 2=

kurang, 3= cukup, 4= baik, 5= sangat baik
Secara umum, dua partisipan memiliki kemampuan manajemen kelas yang cukup baik dan empat partisipan lainnya kurang memiliki kemampuan kelas yang baik, sehingga masih dapat dikembangkan. Wali kelas I dan VI cukup mampu menerapkan rutinitas dan peraturan di kelas, serta menggunakan metode pembelajaran yang cukup bervariasi. Keempat partisipan lain tampak masih kurang memiliki kemampuan hampir di seluruh aspek manajemen kelas. Sementara itu, dalam aspek pengaturan ruang kelas, beberapa partisipan cukup mampu mengatur ruang kelasnya, namun belum optimal. Mayoritas partisipan belum memiliki kemampuan untuk menggunakan strategi penguatan dan pelemahan perilaku selain pujian dan teguran.

Temuan wawancara secara umum mendukung hasil observasi, yaitu para partisipan yang tidak menerapkan aspekaspek manajemen kelas ternyata tidak memahami aspek tersebut yang meliputi manfaat dan cara menerapkannya. Mayoritas partisipan tidak memahami kebutuhan kelasnya, sehingga tidak menerapkan apapun untuk mendukung ketertiban di kelasnya. Beberapa partisipan tidak mau menerapkan hukuman kepada siswanya, sehingga hanya memberikan teguran. Hal ini dikarenakan para partisipan berharap agar para siswa dapat sadar dengan sendirinya.

"Saya gak ngerti harus ngapain biar kelasnya tenang. Sudah dihukum, gak efektif." (Ibu MK, wawancara baseline).

"Biarlah kesadaran sendiri tanpa ada hukuman. Kalaupun ada hukuman, takutnya jadi trauma ke anak-anak. Jadi kita kayak tarik ulur aja, sebentar ada kerasnya sebentar ada lembutnya." (Ibu MR, wawancara baseline). 
Akan tetapi, juga terdapat partisipan yang memahami pentingnya aspek-aspek manajemen kelas dan menerapkannya sejak awal tahun ajaran, sehingga kelasnya sudah cukup tertib saat ini.

"Jadi, ada sosialisasi (peraturan kelas) dulu ke mereka. Jadi ketika saya masuk pun, mereka sudah mulai refleks buang sampah." (Ibu AP wawancara baseline).

"Kalau saya ngajar sebenernya metode pengajaran harus ada alatnya supaya efektif. Kalo gak ada alatnya, kurang efektif kalo kelas I ini... biar anak-anak gak bosen, lebih senang dan tenang belajarnya." (Ibu MD, wawancara baseline).

Berdasarkan hasil data baseline ini, maka peneliti menyusun intervensi yang secara umum bertujuan untuk meningkatkan kemampuan manajemen kelas para partisipan. Intervensi diberikan dalam bentuk pelatihan yang membahas aspekaspek manajemen kelas. Dalam pelatihan, peneliti membahas 4 aspek manajemen kelas karena keempat aspek ini adalah aspek yang kurang dimiliki mayoritas partisipan, yang ditandai dengan nilai Mean di bawah 3. Keempat aspek tersebut adalah penerapan rutinitas $(M=2,17)$, mengajarkan peraturan kelas $(M=2,0)$, menggunakan strategi penguatan perilaku lain $(M=1,33)$, dan menggunakan strategi pelemahan perilaku lain $(M=2,0)$.

Selain keempat aspek tersebut, sebenarnya terdapat dua aspek lain yang juga memiliki nilai Mean di bawah 3, yaitu pengaturan ruang kelas $(M=2,83)$ dan penerapan metode pembelajaran aktif $(M=2,33)$. Akan tetapi, kedua aspek ini tidak diikutsertakan dalam pelatihan karena beberapa alasan. Pertama, para partisipan tidak memiliki kendali penuh untuk mengatur desain fisik ruang kelasnya. Kedua, saat penelitian ini berlangsung, para partisipan juga mendapatkan pelatihan dari sebuah lembaga anak mengenai metode pembelajaran aktif, sehingga peneliti memutuskan untuk tidak membahasnya dalam pelatihan yang peneliti rancang. Setelah pelatihan dilaksanakan, Peneliti kembali melakukan observasi dan refleksi untuk mengetahui apakah terjadi peningkatan kemampuan para partisipan.

Hasil observasi pada Tabel 4 menunjukkan bahwa wali kelas I, II dan V mengalami peningkatan kemampuan manajemen kelas, sementara wali kelas III dan IV masih belum mengalami peningkatan. Wali kelas VI yang pada awalnya memiliki kemampuan manajemen kelas yang tergolong sangat baik, memiliki kemampuan yang konsisten setelah diberikan pelatihan. Beberapa aspek yang mengalami peningkatan adalah penerapan rutinitas, mengajarkan dan menerapkan peraturan, penggunaan strategi dan pelemahan perilaku. Aspek strategi penguatan dan pelemahan perilaku hanya ditemukan meningkat pada dua partisipan yang awalnya memiliki kemampuan manajemen kelas cukup baik.

Meningkatnya kemampuan para partisipan juga didukung hasil refleksi yang menunjukkan bahwa para partisipan memiliki pemahaman yang lebih baik tentang manajamen kelas dan aspek-aspek di dalamnya. Para partisipan yang telah menerapkan materi pelatihan merasa bahwa hal tersebut efektif diterapkan di kelasnya, sehingga siswa menjadi lebih tertib dibandingkan sebelumnya.

"Setelah pelatihan kemarin, akhirnya saya coba buat peraturan baru. Peraturannya jadi lebih sedikit, 5 poin aja. Lalu, saya hias juga supaya anak-anak bisa lebih tertarik baca dan ingat. Kemarin baru saya ulangi ke anak-anak, dibacakan lagi satu-satu. Lumayan, ternyata efektif. Kelas ini sudah mulai lebih tenang sekarang. "(Ibu MR, wawancara pasca pelatihan). 
"Saya sudah mulai terapkan kebiasaan-kebiasaan baru di kelas, seperti membuang sampah hanya boleh pas istirahat, menyerut pensil juga. Jadi anak-anak tidak berkeliaran pas saya ngajar. Ternyata ampuh ya. Anak-anak mau nurut jadi gak jalan-jalan lagi. Paling masih ada satu dua anak saja yang kadang gak nurut." (Ibu AT, wawancara pasca pelatihan).

Tabel 4.

Perolehan Skor Observasi Pasca Intervensi Siklus 1

\begin{tabular}{|c|c|c|c|c|c|c|c|}
\hline \multirow{2}{*}{ No } & \multirow{2}{*}{ Aspek } & \multicolumn{6}{|c|}{ Kelas } \\
\hline & & I & II & III & IV & V & VI \\
\hline \multirow[t]{2}{*}{1} & Rutinitas & 4 & $\underline{2}$ & 2 & 1 & 1 & 4 \\
\hline & $\begin{array}{l}\text { Pengaturan } \\
\text { ruang }\end{array}$ & 4 & 2 & 2 & 3 & 2 & 4 \\
\hline \multirow[t]{2}{*}{2} & $\begin{array}{l}\text { Mengajarkan } \\
\text { aturan }\end{array}$ & 3 & 3 & 1 & 1 & $\underline{\mathbf{3}}$ & 3 \\
\hline & $\begin{array}{l}\text { Menerapkan } \\
\text { aturan }\end{array}$ & 4 & 4 & 3 & 3 & 3 & 4 \\
\hline \multirow[t]{2}{*}{3} & $\begin{array}{l}\text { Menggunakan } \\
\text { choral } \\
\text { responding dan } \\
\text { response cards }\end{array}$ & 2 & $\underline{4}$ & 2 & 2 & 2 & 4 \\
\hline & $\begin{array}{l}\text { Metode } \\
\text { mengajar yang } \\
\text { lain }\end{array}$ & $\underline{4}$ & $\underline{\mathbf{3}}$ & 2 & 2 & $\underline{\mathbf{3}}$ & 3 \\
\hline \multirow[t]{2}{*}{4} & $\begin{array}{l}\text { Menggunakan } \\
\text { pujian untuk } \\
\text { apresiasi }\end{array}$ & 4 & 4 & 3 & 3 & 4 & 4 \\
\hline & $\begin{array}{l}\text { Menggunakan } \\
\text { strategi } \\
\text { penguatan } \\
\text { perilaku lain }\end{array}$ & 2 & 1 & 1 & 1 & 1 & $\underline{4}$ \\
\hline \multirow[t]{2}{*}{5} & $\begin{array}{l}\text { Menggunakan } \\
\text { teguran }\end{array}$ & 4 & 4 & 2 & 3 & 2 & 4 \\
\hline & $\begin{array}{l}\text { Menggunakan } \\
\text { strategi } \\
\text { pelemahan } \\
\text { perilaku lain }\end{array}$ & $\underline{\mathbf{3}}$ & 2 & 2 & 2 & 2 & $\underline{\mathbf{3}}$ \\
\hline \multicolumn{2}{|c|}{ Total Skor } & 34 & 29 & 20 & & 23 & 37 \\
\hline \multicolumn{2}{|c|}{ Kategori } & 5 & 4 & 2 & 2 & 3 & 5 \\
\hline
\end{tabular}

Keterangan: Kategori: 1= sangat kurang, 2= kurang, 3= cukup, 4= baik, 5= sangat baik

Catatan: Skor yang dicetak tebal dan diberi garis bawah adalah skor yang mengalami peningkatan setelah diberikan pelatihan. [rating bersifat subjektif, tidak bisa dianggap sebagai hasil pengukuran, sehingga analisisnya harus melihat pada jenis data yang didapatkan].

Partisipan yang sebelumnya telah menerapkan rutinitas dan peraturan dengan baik di kelas, merasa bahwa strategi penguatan dan pelemahan perilaku ternyata penting dan dapat membantu penerapan peraturan di kelas. Pada partisipan yang belum menerapkan peraturan dan rutinitas dengan benar sejak awal, mereka merasa bahwa mengajarkan rutinitas dan peraturan sangat penting di kelas. Hal ini tampak dari perilaku siswa yang lebih terarah. Akan tetapi, mereka masih kesulitan dalam menerapkan konsekuensi perilaku karena merasa belum terlalu memahami dan banyak hal yang perlu dipersiapkan, selain mengerjakan tanggung jawab lain.

Sementara itu, pada partisipan yang tidak mengalami peningkatan, kesibukan di luar mengajar menjadi alasan utama mereka belum sempat memikirkan dan menerapkan materi pelatihan. Peneliti sendiri merasa bahwa pendekatan yang lebih personal dalam melaksanakan intervensi penting dilakukan agar para partisipan dapat lebih memahami manfaat dan cara penerapan masing-masing aspek yang disesuaikan dengan kondisi kelas masing-masing. Para partisipan juga tampak lebih terbuka dan mau berdiskusi dalam situasi personal dibandingkan kelompok.

Coaching secara individual dilakukan hanya kepada empat partisipan (kelas II, III, IV, dan V) karena berdasarkan hasil observasi pasca intervensi 1, kemampuan manajemen kelas keempat partisipan ini masih dapat dikembangkan lebih lanjut. Sementara itu, dua partisipan (kelas I dan VI) sudah memiliki kemampuan manajemen kelas yang tergolong sangat baik, sehingga tidak perlu diintervensi lebih lanjut.

Secara umum, hasil observasi yang tampak pada Tabel 5 menunjukkan para partisipan yang mengikuti coaching mengalami peningkatan kemampuan manajemen kelas. Hampir seluruh partisipan menerapkan rutinitas, walaupun masih ada yang kurang konsisten. Mereka juga mampu membuat dan mengajarkan peraturan kelas kepada siswa, serta mulai 
menerapkan strategi penguatan dan pelemahan perilaku, walaupun masih perlu dikembangkan lebih lanjut. Para partisipan juga menggunakan variasi metode pembelajaran aktif.

Tabel 5.

Perolehan Skor Observasi Pasca Intervensi Siklus 2

\begin{tabular}{|c|c|c|c|c|c|c|c|}
\hline \multirow{2}{*}{ No } & \multirow{2}{*}{ Aspek } & \multicolumn{6}{|c|}{ Kelas } \\
\hline & & I & II & III & IV & $\mathrm{V}$ & VI \\
\hline \multirow[t]{2}{*}{1} & Rutinitas & 4 & 4 & 2 & 1 & 2 & 4 \\
\hline & Pengaturan ruang & 4 & $\underline{\overline{3}}$ & 2 & 3 & $\overline{2}$ & 4 \\
\hline \multirow[t]{2}{*}{2} & Mengajarkan aturan & 3 & 3 & $\underline{4}$ & $\underline{4}$ & 3 & 3 \\
\hline & Menerapkan aturan & 4 & 4 & $\underline{4}$ & $\overline{3}$ & 3 & 4 \\
\hline \multirow[t]{2}{*}{3} & $\begin{array}{l}\text { Menggunakan } \\
\text { choral responding } \\
\text { dan response cards }\end{array}$ & $\underline{4}$ & $\underline{4}$ & 2 & 2 & 2 & 4 \\
\hline & $\begin{array}{l}\text { Metode mengajar } \\
\text { yang lain }\end{array}$ & 4 & $\underline{4}$ & 2 & 2 & 3 & 3 \\
\hline \multirow[t]{3}{*}{4} & Menggunakan & 4 & 4 & 3 & $\underline{4}$ & 4 & 4 \\
\hline & $\begin{array}{ll}\text { pujian } & \text { untuk } \\
\text { apresiasi } & \end{array}$ & & & & & & \\
\hline & $\begin{array}{l}\text { Menggunakan } \\
\text { strategi penguatan } \\
\text { perilaku lain }\end{array}$ & $\underline{\mathbf{3}}$ & $\underline{\mathbf{2}}$ & $\underline{\mathbf{2}}$ & $\underline{2}$ & $\underline{\mathbf{2}}$ & 4 \\
\hline \multirow[t]{2}{*}{5} & $\begin{array}{l}\text { Menggunakan } \\
\text { teguran }\end{array}$ & 4 & 4 & $\underline{\mathbf{3}}$ & 3 & $\underline{4}$ & 4 \\
\hline & $\begin{array}{l}\text { Menggunakan } \\
\text { strategi pelemahan } \\
\text { perilaku lain }\end{array}$ & 3 & $\underline{\mathbf{3}}$ & 2 & 2 & 2 & 3 \\
\hline \multicolumn{2}{|c|}{ Total Skor } & 37 & 35 & 26 & 26 & 27 & 37 \\
\hline \multicolumn{2}{|c|}{ Kategori } & 5 & 5 & 3 & 3 & 3 & 5 \\
\hline
\end{tabular}

Keterangan: Kategori: $1=$ sangat kurang, $2=$ kurang, $3=$ cukup, $4=$ baik, $5=$ sangat baik

Catatan: Skor yang dicetak tebal dan diberi garis bawah adalah skor yang mengalami peningkatan setelah diberikan coaching.

Meningkatnya kemampuan para partisipan ini didukung dengan hasil wawancara. Para partisipan lebih memahami pentingnya manajemen kelas dan aspek-aspek di dalamnya, sehingga dapat menerapkannya di kelas. Mereka menyadari bahwa peraturan penting untuk dibuat bersama siswa dan diterapkan konsisten di kelas. Mereka juga memahami akan pentingnya konsekuensi perilaku sebagai tindak lanjut dari penerapan tersebut.

"Setelah saya memikirkan dan mendiskusikan peraturan kelas bersama anak-anak, akhirnya kami sepakat untuk membuat 4 poin peraturan kelas yang baru. Nah, 4 poin ini seperti yang kemarin kita bahas, saya terapkan pakai token economies juga. Anak-anak senang. Mereka minta sebelum jam pulang sekolah untuk dibacakan jumlah poin mereka." (Bapak HL, wawancara pasca coaching).

Para partisipan kini menyadari adanya perubahan di kelasnya, yakni para siswa menjadi lebih tertib. Akan tetapi, masih ada kesulitan yang dihadapi partisipan dan belum bisa teratasi. Kesulitan ini berupa perilaku dua hingga tiga siswa di kelas yang masih belum dapat dikendalikan.

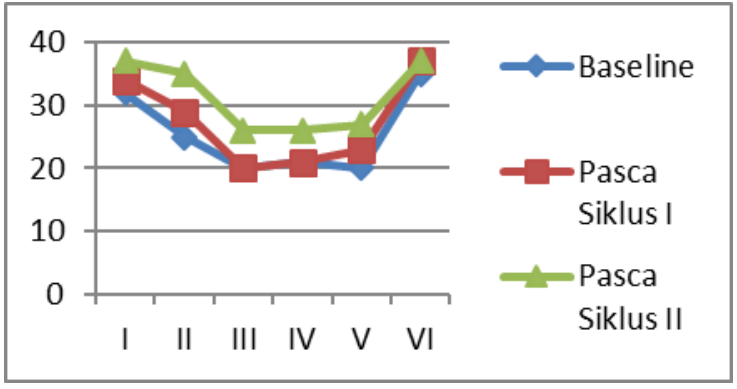

Gambar 1. Perbandingan Skor Hasil Observasi Keterampilan Manajemen Kelas Wali Kelas

Berdasarkan grafik 1, maka dapat disimpulkan bahwa para partisipan mengalami peningkatan kemampuan manajemen kelas setelah diberikan dua kali intervensi berupa pelatihan dan coaching. Hal ini sejalan dengan pendapat Marzano, Marzano, dan Pickering (2003) yang menyatakan bahwa manajemen kelas adalah kemampuan yang dapat dipelajari. Melatih guru untuk meningkatkan kemampuan manajemen kelasnya dapat mengubah perilaku guru, sehingga pada akhirnya dapat mengubah perilaku siswa dan berdampak pada pencapaian akademik siswa secara positif.

Berdasarkan grafik 1, ditemukan bahwa intervensi berupa coaching lebih efektif dibandingkan pelatihan. Para partisipan ditemukan mengalami peningkatan kemampuan yang lebih menonjol setelah diberikan coaching dibandingkan 
pelatihan. Dengan metode coaching, partisipan mengalami peningkatan maksimum 6 poin dan minimum 4 poin setelah diberikan coaching. Sementara itu, dengan metode pelatihan, para partisipan hanya mengalami peningkatan kemampuan maksimum 4 poin dan terdapat dua partisipan yang tidak mengalami peningkatan sama sekali. Temuan penelitian ini sejalan dengan pendapat Joyce \& Showers (dalam Becker et al., 2013) bahwa pelatihan yang umumnya berisi penyampaian klasikal, latihan, dan umpan balik verbal berdampak kecil terhadap praktik guru. Oleh karena itu, Becker dkk. (2013) meyakini bahwa coaching secara personal dapat dilakukan sebagai intervensi lanjutan dari sebuah pelatihan.

Pendapat di atas sejalan dengan hasil wawancara dalam evaluasi intervensi. Beberapa partisipan menyatakan bahwa mereka merasa merasa dapat lebih leluasa berdiskusi dan lebih banyak membahas aspek-aspek manajemen kelas yang dapat diterapkan sesuai kondisi kelasnya masingmasing. Selain itu, peneliti juga dapat lebih fokus mengembangkan aspek-aspek manajemen kelas yang perlu dikembangkan masing-masing partisipan secara lebih detail, sehingga para partisipan dapat langsung menerapkan apa yang menjadi bahan diskusi dengan peneliti. Hal ini berbeda dari pelatihan yang kurang memberikan mereka kesempatan untuk banyak berdiskusi dengan peneliti, sehingga mereka hanya menerapkan apa yang mereka pahami dan tidak mengubah aspek-aspek manajemen kelas yang tidak mereka pahami. Hal ini menyebabkan para partisipan mengalami lebih sedikit peningkatan setelah diberikan pelatihan dibandingkan setelah diberikan coaching.

Penelitian ini juga menghasilkan temuan lain. Terkait dengan latar belakang pendidikan dan pengalaman bekerja, para partisipan dengan latar belakang pendidikan guru dan memiliki pengalaman bekerja di bidang pendidikan yang cukup lama ditemukan memiliki kemampuan manajemen kelas yang baik. Temuan ini sejalan dengan hasil penelitian Dincer dan Akgun (2015) yang menemukan bahwa guru dengan pengalaman mengajar selama 6 tahun ke atas memiliki kemampuan manajemen kelas yang lebih baik dibandingkan dengan guru dengan pengalaman mengajar 0 hingga 5 tahun. Hal ini mengindikasikan bahwa semakin banyaknya pengalaman profesional dalam mengajar dapat berdampak positif terhadap kemampuan manajemen kelasnya. Pengalaman mengajar dapat berdampak signifikan terhadap kemampuan manajemen kelas. Akan tetapi, ia tidak dapat berdiri sendiri sebagai satu faktor, melainkan harus digabungkan dengan faktor-faktor lain, seperti atribusi personal (kesabaran, rasa tanggung jawab, kemauan) dan pengetahuan yang relevan digunakan dalam praktik profesional.

Pentingnya pengalaman mengajar dalam manajemen kelas juga ditemukan dalam penelitian Bullock, Coplan, dan Bosacki (2015) yang menyatakan bahwa guru dengan pengalaman mengajar yang lama dapat menggunakan kemampuan mereka secara aktif untuk mengelola perilaku siswanya sehari-hari. Mereka juga memiliki pengalaman nyata untuk mengendalikan perilaku siswa yang tergolong sulit, sehingga dapat langsung diterapkan dan membuat kepercayaan diri mereka dalam manajemen kelas meningkat.

Beberapa partisipan juga ditemukan memiliki latar belakang pendidikan guru sebagai modalitas dasar mereka dalam mengajar, yaitu wali kelas I, III, dan VI. Selain memiliki pendidikan yang mendukung profesinya saat ini, wali kelas I dan VI juga memiliki pengalaman mengajar yang sudah cukup lama. Lain halnya dengan wali kelas III. Walaupun ia memiliki latar belakang pendidikan guru, 
namun pengalamannya masih minim.

Pahl (2008) menjelaskan bahwa tingkat pendidikan guru tidak dapat menjadi jaminan bahwa ia akan menampilkan performa yang baik dalam mengajar. Kemampuannya sangat tergantung pada seberapa dekat kemiripan karakteristik akan apa yang dipelajari sewaktu mengemban pendidikan dan kenyataan yang dihadapi di kelas. Oleh sebab itu, Pahl (2008) menyimpulkan bahwa latar belakang pendidikan bukanlah satusatunya hal yang menjadi dasar kemampuan guru. Dengan demikian, dapat disimpulkan bahwa latar belakang pendidikan didukung dengan pengalaman mengajar yang kaya dapat berdampak besar terhadap kemampuan para guru dalam mengajar.

Dalam proses penelitian tindakan ini, evaluasi pelatihan dilakukan setelah dua minggu usai pelatihan dilaksanakan. Sementara itu, evaluasi coaching dilakukan hanya satu minggu setelah coaching dilaksanakan. Menurut Phillips dan Phillips (2016), pengetahuan atau kemampuan yang baru dipelajari sangat penting untuk digunakan secepatnya dan diperkuat secara berkala. Oleh karena itu, evaluasi pengetahuan atau kemampuan baru ini dilakukan dalam hitungan minggu, umumnya dua hingga tiga minggu setelah intervensi diberikan. Periode waktu ini cukup bagi individu untuk mempelajari dan menerapkan pengetahuan atau kemampuan baru tersebut.

Mengacu kepada pernyataan Phillips dan Phillips (2016) di atas, maka waktu intervensi coaching dalam penelitian ini masih belum ideal, karena sudah dilakukan kurang dari dua minggu setelah coaching. Evaluasi dilakukan cepat karena terbatasnya waktu penelitian yang ada. Peneliti menyadari bahwa waktu tersebut sangat singkat bagi para partisipan untuk mempersiapkan diri, sehingga materi coaching belum sepenuhnya ditampilkan.
Pada beberapa aspek, para wali kelas juga baru mempraktekkannya selama dua hingga tiga hari, sehingga tingkat implementasinya masih tinggi. Dalam hal ini, peneliti menyadari bahwa seharusnya ada periode waktu yang cukup panjang agar partisipan dapat mempersiapkan diri dengan baik dan kemampuan yang muncul juga dipastikan konsisten.

Walaupun penelitian ini tidak secara khusus menggali faktor-faktor yang mempengaruhi kemampuan manajemen kelas, namun ada beberapa faktor yang ditemukan di lapangan dan berdampak kepada kemampuan manajemen kelas para partisipan. Pertama, ukuran kelas. Dash dan Dash (2008) mengungkapkan bahwa semakin sedikit jumlah siswa di kelas, maka akan semakin mudah bagi guru untuk menerapkan manajemen kelas dan sebaliknya. Temuan penelitian mendukung hal ini. Jumlah siswa kelas I ditemukan lebih sedikit dibandingkan siswa di kelaskelas lainnya, yaitu 12 siswa. Hal ini diakui oleh wali kelas I, bahwa jumlah siswa yang sedikit lebih memudahkannya untuk melakukan manajemen kelas. Wali kelas III yang pernah menggantikan wali kelas I selama satu hari juga menyatakan bahwa jumlah siswa yang lebih sedikit sangat membantu memudahkan penerapan manajemen kelas. Sedikitnya siswa dirasa dapat mempermudah guru untuk mengawasi para siswa, sehingga faktor ini ditemukan mempengaruhi kemampuan manajemen kelas para partisipan di SD X.

Faktor kedua adalah homogenitas. Dash dan Dash (2008) menyatakan bahwa manajemen kelas cenderung lebih mudah diterapkan pada kelas dengan karakteristik siswa yang homogen dibandingkan heterogen. Siswa SD $X$ memiliki karakteristik yang cenderung homogen. Menurut hasil wawancara dengan pihak sekolah, mayoritas siswa tinggal di lingkungan yang berdekatan dengan sekolah dan memiliki latar belakang keluarga yang mirip satu dengan yang lain. 
Hal ini dapat memudahkan guru untuk menerapkan kemampuan manajemen kelas. Temuan penelitian juga mendukung pernyataan ini. Para partisipan yang menerapkan aspek-aspek manajemen kelas merasa bahwa kelasnya menjadi lebih tertib dibandingkan sebelumnya secara keseluruhan, walaupun ada beberapa siswa yang perilakunya masih sulit diatasi. Hal ini menunjukkan bahwa strategi manajemen kelas yang sama dapat efektif kepada hampir seluruh siswa.

Faktor selanjutnya adalah karakteristik guru. Menurut Dash dan Dash (2008), guru yang bersahabat, antusias, memiliki banyak pengetahuan, berpengalaman, dan berperan sebagai pemimpin dan fasilitator belajar di kelas cenderung lebih disukai siswa dan lebih mudah bagi guru untuk mengatur kelasnya, menjaga kedisiplinan, dan mendorong siswa belajar. Hasil penelitian menunjukkan bahwa wali kelas di kelas I dan VI memiliki karakteristik ini. Temuan observasi menunjukkan bahwa kedua partisipan ini menampilkan perilaku bersahabat, antusias, dan senang berdiskusi dengan siswanya, sehingga para siswa juga tampak tertarik dengan mereka. Kedua partisipan ini juga tampak memiliki kedekatan dengan para siswanya, yang ditandai dengan interaksi hangat yang terjalin di kelas. Para partisipan ini sering mengajak siswa berbicara secara personal dan seringkali bergurau dengan siswa. Beberapa siswa juga didapati mau menceritakan kesulitan atau masalahnya kepada kedua wali kelasnya. Hal ini diperkuat dengan pernyataan kedua partisipan dalam wawancara, bahwa para siswa telah merasa dekat dengan mereka, sehingga lebih memudahkan bagi mereka untuk menjaga kedisiplinan dan mengatur kelasnya.

Ketiga faktor di atas adalah beberapa faktor yang kuat ditemukan mempengaruhi manajemen kelas guru di SD X. Peneliti mengakui bahwa salah satu kelemahan penelitian ini adalah kurang menggali lebih jauh mengenai faktor-faktor yang mempengaruhi kemampuan manajemen kelas guru, sehingga dapat menjadi saran bagi penelitian selanjutnya bila penelitian serupa akan dilakukan oleh peneliti maupun pihak lain.

Walaupun penelitian ini memusatkan fokus pada kemampuan manajemen kelas guru dalam mengendalikan situasi kelas, namun sebenarnya faktor keluarga juga berperan besar. Reglin, Akpo-Sanni, dan Losike (2012) mengungkapkan bahwa situasi keluarga sangat berkaitan dengan perilaku anak-anak dari kalangan SES rendah. Penggunaan kekerasan di rumah sebagai cara mengendalikan perilaku anak, kurangnya disiplin atau struktur di dalam keluarga, kurangnya perhatian dari orang tua turut berperan besar dalam membentuk perilaku para siswa.

Hal ini sebenarnya juga tampak kuat pada siswa di SD $X$. Karakteristik situasi keluarga di atas juga diungkapkan oleh partisipan. Partisipan menyatakan para siswa, terutama siswa dari panti asuhan, sangat sering diberikan hukuman fisik yang keras. Para orang tua juga kurang memahami cara mendidik anak sehingga cenderung tidak sabar dalam mengasuh anak. Bukti observasi dan wawancara dengan partisipan menunjukkan bahwa beberapa orang tua mudah memukul anaknya, bahkan di sekolah, sehingga siswa sudah terbiasa dengan kekerasan. Partisipan juga menuturkan para siswa dibiarkan bebas beraktivitas di rumah tanpa kontrol orang tua. Hal ini terbukti dari PR yang seringkali tidak dikerjakan, walaupun orang tua mengetahuinya. Dengan demikian, hal ini menunjukkan bahwa selain kemampuan guru yang perlu dibenahi, pemahaman orang tua akan pentingnya mendidik anak dengan tepat juga perlu menjadi fokus.

\section{SIMPULAN}

Penelitian ini menunjukkan efektivitas intervensi terhadap peningkatan 
kemampuan manajemen kelas guru. Di samping itu, intervensi berupa coaching individual ditemukan lebih efektif dibandingkan pelatihan. Temuan penelitian juga menunjukkan bahwa latar belakang pendidikan, pengalaman bekerja, ukuran kelas, homogenitas, dan karakteristik guru merupakan faktor-faktor yang berpengaruh terhadap kemampuan manajemen kelas guru. Penelitian selanjutnya dapat menggali faktor-faktor lain yang mungkin berpengaruh terhadap manajemen kelas partisipan.

\section{DAFTAR PUSTAKA}

Aguilar, E. (2013). The art of coaching: Effective strategies for school transformation. San Fransisco: John Wiley \& Sons, Inc.

Becker, K. D., Darney, D., Domitrovich, C., Keperling, J. P., \& Ialongo, N. S. (2013). Supporting universal prevention programs: A two-phased coaching model. Clinical Child \& Family Psychology, 16(2), 213-228.

Bullock, A., Coplan, R. J., \& Bosacki, S. (2015). Exploring links between early childhood educators'psychological

characteristics and classroom management self-efficacy beliefs. Canadian Journal of Behavioural Science, 47(2), 175-183.

Dash, M., \& Dash, N. (2008). School management. New Delhi: Atlantic Publishers \& Distributors Ltd.

Dincer, C., \& Akgun, E. (2015). Developing a classroom management skills inventory for preschool teachers and the correlation of preschool teachers' classroom management skills with different variables. Education and Science, 40(177), 187-201.
Emmer, E. T., \& Stough, L. M. (2001). Classroom management: A critical part of educational psychology, with implications for teacher education. Educational Psychologist, 36(2), 103-112.

Goh, S. C., \& Khine, M. S. (2002). Studies in educational learning environments: An international perspective. Singapura: World Scientific Publishing.

Graham, M., Milanowski, A., \& Miller, J. (2012). Measuring and promoting inter-rater agreement of teacher and principal performance ratings. New York: Center for Educator Compensation Reform.

Greenwood, D. J. \& Levin, M. (2007). Introduction to action research: Social research for social change. California: SAGE Publications, Inc.

Jensen, E. (2013). How poverty affects classroom engagement. Faces of Poverty, 70(8), 24-30.

Marzano, R. J., Marzano, J. S., \& Pickering, D. (2003). Classroom management that works: Researchbased strategies for every teacher. Vancouver: Association for Supervision and Curriculum Development.

McGrath, P. J. \& Elgar, F. (2015). Effect of socio-economic status on behavioral behaviors.

International Encyclopedia of the Social \& Behavioral Sciences, 2, 477-480.

Pahl, L. (2008). Teacher quality and effectiveness: What does the educational literature say? A call for a new paradigm. Salt Lake City: Aardvark Global Publishing.

Phillips, J. J. \& Phillips, P. P. (2016). Handbook of training evaluation and 
measurement methods. New York: Routledge.

Poerwandari, K. (2009). Pendekatan kualitatif untuk penelitian perilaku manusia. Jakarta: Lembaga Pengembangan Sarana Pengukuran dan Pendidikan Psikologi (LPSP3) Fakultas Psikologi Universitas Indonesia.

Rachman. (2015). Pentingnya pendidikan sekolah dasar. Diakses pada tanggal 12016 Mei dari https://disdik.bekasikab.go.id/beritapentingnya-pendidikan-sekolahdasar.html

Ratcliff, N. J., Jones, C. R., Costner, R. H., Savage-Davis, E., Sheehan, H., \& Hunt, G. H. (2011). Teacher classroom management behaviors and student time-on-task: Implications for teacher education. Action in Teacher Education, 32(4), 38-51.

Reglin, G., Akpo-Sanni, J., \& LosikeSedimo, N. (2012). The effect of a professional development classroom management model on at-risk elementary students' misbehavior. Education, 133(1), 3-17.

Reinke, W. M., Stormont, M., Herman, K.C., \& Newcomer, L. (2014). Using coaching to support teacher implementation of classroom-based intervention. Behavioral Education, 23, 150-167.
Sa'diyah, C. \& Sukayati. F (2011). Pengelolaan kelas dan penerapannya dalam pembelajaran matematika di SD. Jakarta: Pusat Pengembangan dan Pemberdayaan Pendidik dan Tenaga Kependidikan (PPPPTK) Matematika.

Sagor, R. (2000). Guiding school improvement with action research. Virginia: Association for Supervision and Curriculum Development.

Santoso, B. (2010). Panduan penyelenggaraan pelatihan. Jakarta: Yayasan Terumbu Karang Indonesia.

Simonsen, B., Fairbanks, S., Briesch, A., Myers, D., \& Sugai, G. (2008). Evidence-based practices in classroom management: Considerations for research to practice. Education \& Treatment of Children, 31(3), 351-380.

Smith, S. C. (2012). Cultural relay in early childhood education: Methods of teaching school behavior to low income children. Urban Rev., 44, 571-588.

Tashakkori, A. \& Teddlie, C. (2010). SAGE handbooks of mixed methods in social \& behavioral research. California: SAGE Publications, Inc.

Willingham, D. T. (2012). Why does family wealth affect learning? American Educator, 36(1), 33-39. 